\title{
PREVALÊNCIA DA LEUCOSE ENZOÓTICA BOVINA EM BÚFALAS (Bos bubalus), DA REGIÃO DE CURITIBA PR
}

(Prevalence of enzootic bovine leukosis in buffaloes (Bos bubalus) from Curitiba region - PR)

Tais Casonato Rodrigues, Louise Krueger, Pedro Henrique Alves da Silva, Alexander Welker Biondo, Louise Nicolle Bach
Kmetiuk, Carolina Dutra Minozzo, Ivan Roque de Barros Filho

Universidade Federal do Paraná, Curitiba, Paraná, Brasil.

*Correspondência: louisekrueger@hotmail.com

RESUMO: A leucose enzoótica bovina (LEB) é uma enfermidade viral crônica de ampla distribuição em rebanhos bovinos, que também pode acometer bubalinos. O agente etiológico é o vírus da leucose bovina (BLV) pertencente à família Retroviridae. Alguns animais infectados pelo BLV podem desenvolver linfocitose persistente e linfomas em 2 a $5 \%$ dos animais (Leuzzi Junior et al., 2001). Todavia a maioria dos animais infectados com o vírus são assintomáticos. A transmissão do vírus ocorre por contato com o sangue de animais infectados. Os linfócitos contaminados podem ser disseminados de animal para animal a partir do uso de luvas de palpação reutilizadas, vacinações, materiais cirúrgicos, entre outros. Em rebanhos de vacas leiteiras a prevalência do BLV tende a ser maior que em bovinos destinados a corte, pois o manejo costuma ser mais intensivo. No Paraná aproximadamente $50 \%$ das vacas da raça Holandesa Preta e Branca são positivas para a LEB (Sponchiado, 2008). A criação de búfalos é relativamente expressiva neste estado e coexistem criações para produção de carne, leite ou ambos. Para este trabalho foram colhidas 75 amostras de sangue de búfalas adultas, provenientes de quatro propriedades da região metropolitana de Curitiba - PR, sendo que em três delas os animais eram destinados a produção de carne e em uma para produção de leite. Após a colheita, o soro sanguíneo foi separado e armazenado congelado até a realização da prova diagnóstica. As amostras séricas foram examinadas pela técnica de imunodifusão em gel de ágar (IDGA), que detecta anticorpos séricos específicos antiBLV por meio de um substrato gelatinoso utilizando-se da glicoproteína gp51 como antígeno. Das 75 amostras, $6(8,0 \%)$ foram positivas, as quais todas eram provenientes da mesma propriedade, que criava búfalas para produção de leite. Das 26 amostras colhidas em tal propriedade, $6(23,1 \%)$ foram positivas para anticorpos contra o BLV. Nenhum animal foi positivo para o BLV dentre os 49 animais testados nas três propriedades destinadas a produção de carne. Os resultados obtidos neste trabalho são semelhantes aos encontrados em estudos realizados para detecção de anticorpos anti-BLV em bovinos, onde a prevalência em animais leiteiros é bastante superior àqueles de criação extensiva destinados à produção de carne. Conclui-se que o vírus da LEB circula em bubalinos criados na região de Curitiba - PR e mais estudos devem ser realizados para melhor avaliação da situação da doença no Estado.

Palavras-chaves: bubalinos; linfoma; vírus

\section{Referências}

LEUZZI JUNIOR, L.A.; ALFIERI, A.F.; ALFIERI, A.A. Leucose enzoótica bovina e vírus da leucemia bovina. SEMINA, v.22, n.2, p.211-221, 2001.

SPONCHIADO, D. Prevalência de anticorpos séricos anti-vírus da leucose enzoótica bovina em rebanhos da raça Holandesa Preta e Branca, criados no estado do Paraná. 2008. Curitiba, $101 \mathrm{f}$. Dissertação (Mestrado em Ciência Veterinárias) - Curso de Pós-graduação em Ciências Veterinárias, Universidade Federal do Paraná. 